DOI: 10.15290/bsp.2017.22.02.10

\title{
Krzysztof Michalak
}

Uniwersytet Jagielloński

k.michalak@doctoral.uj.edu.pl

\section{Jakub Grzegorz Firlus}

Uniwersytet Jagielloński

firlus.jakub@gmail.com

\section{Administracyjnoprawne ograniczenia autonomii pacjenta - uwagi wokół przymusu leczenia}

\section{Administrative limitations of patient's autonomy - remarks on involuntary treatment}

\begin{abstract}
Public administration operates under a wide variety of legal forms and regulates a broad range of the citizenries day-to-day activities. Amongst the many subjects of state interest, vital for the self-determination of individuals, is that of disease surveillance which is conducted by specialized organs of state - the so-called 'administrative police'. Under the competences of epidemic intelligence, public authorities may intervene in the scope of patient autonomy, for example by imposing compulsory vaccination. However, the standards of procedure involved are questionable insofar that they represent little more than an adjudicative, 'court-room' style, adversarial process of decision-making. This seems to lessen the right to fair administrative justice and as such may be recognized as being unconstitutional. This is to say that administra-tive proceedings are not coherent with the essence of patient autonomy doctrine (concept). In this study the authors address several issues connected both with the legal framework of pro-ceedings before the 'administrative police' and judicial review of public authorities' actions which are affecting the individual's right to self-determination.
\end{abstract}

Keywords: regulatory power, administrative proceedings, involuntary treatment, disease surveillance Słowa kluczowe: działalność reglamentacyjna, postępowania administracyjne, przymus leczenia, nadzór epidemiologiczny

\section{Uwagi wprowadzające}

Zasada autonomii pacjenta na gruncie etyki lekarskiej sprowadza się do prawidłowości, według której zabiegi lekarskie na osobie autonomicznej mogą być doko- 
nywane jedynie za jej zgodą ${ }^{1}$ W ukształtowaniu wielu kluczowych instytucji prawa medycznego, takich jak np. tajemnica lekarska, wyraźnie dostrzegalny jest refleks respektu dla autonomii pacjenta ${ }^{2}$. Wzgląd na autonomiczność pacjenta w postępowaniu terapeutycznym w pełnej jaskrawości unaocznia napięcie pomiędzy paternalizmem $^{3}$ a indywidualizmem (autonomią) ${ }^{4} \mathrm{w}$ funkcjonowaniu systemu ochrony zdrowia in genere. Wskazuje zatem na immanentne dla działalności leczniczej konflikty dóbr w medycynie ${ }^{5}$, czy też notoryczną wręcz sporność prawniczych zagadnień interpretacyjnych z nimi związanych ${ }^{6}$.

Teza o limitującej roli administracyjnoprawnych środków ingerencji w autonomię pacjenta była już przedmiotem uwagi piśmiennictwa ${ }^{7}$. Jakkolwiek dotychczasowe opracowania w mniejszym stopniu stanowiły studia $\mathrm{z}$ zakresu analizy właściwych cech systemowych nawiązujących do praktyki funkcjonowania administracji publicznej. Stąd też niniejszy artykuł można potraktować jako porządkujący zagadnienia sygnalizowane we wcześniejszych opracowaniach. Jak się wydaje, szczególna pozycja pacjenta jako adresata czynności organów administrujących czyni realną potrzebę rewizji dostępnych form oddziaływania nań oraz weryfikacji podjętych czynności mających na celu egzekwowanie nałożonych przez administrację publiczną obowiązków. Niebagatelny wpływ na dobór tematu miała tocząca się obecnie dyskusja dotycząca proceduralnych ram działalności administracji publicznej wobec jednostki ${ }^{8}$. Stąd też aktualne pozostaje zagadnienie adekwatności posługiwania się przez ustawodawcę formami administracyjnoprawnej reglamentacji. W ramach wstępnych uwag wypadnie dodatkowo zaznaczyć, iż poniższe rozważania dotyczą jedynie pro-

1 Por. W. Załuski, Autonomia, (w:) A. Górski (red.), Leksykon prawa medycznego - 100 podstawowych pojęć, Warszawa 2012, s. 3.

2 Por. K. Michalak, „Tajemnica lekarska jako gwarancja autonomii pacjenta - krytyczna analiza dogmatyki”. Wybrane, przywoływane w niniejszym opracowaniu tezy, zostały wygłoszone w trakcie Il Ogólnopolskiej Konferencji Naukowej Prawa Pacjenta „Granice autonomii pacjenta”. W tekście uwzględniono i rozwinięto wyniki dyskusji toczonej podczas konferencji.

3 Co do pojęcia na gruncie prawa medycznego por. W. Załuski, (w:) Autonomia..., op. cit., s. 145. Por. także: H.R. Wulff, S.A. Pedersen, R. Rosenborg (przeł. Z. Szarawarski), Filozofia medycyny - wprowadzenie, Warszawa 1993, s. 237 i n. Por także: B. Gert, C.M. Culver, K.D. Clouser, Paternalism and Its Justification, (w:) Bioethics: A systematic approach, Oxford 2006, passim.

4 Co do pojęcia na gruncie prawa medycznego por. W. Załuski, (w:) Autonomia..., op. cit., s. 1.

5 Szeroko na temat konfliktów dóbr w medycynie por. A. Górski, Leczyć czy nie leczyć? Dylematy podejmowania leczenia z punktu widzenia konfliktu dóbr, „Czasopismo Prawa Karnego i Nauk Penalnych” 2011, wydanie specjalne, s. 151-160. Ponadto: Tenże, Lekarz w procesie karnym (wybrane zagadnienia), (w:) P. Kardas, T. Sroka, W. Wróbel (współred.), Państwo prawa i prawo karne. Księga jubileuszowa Profesora Andrzeja Zolla, t. 2, Warszawa 2012, s. 1597 i n.

6 W tym duchu: K. Gromek, Ustawa o ochronie zdrowia psychicznego. Komentarz, Warszawa 2004, s. 9., w tym duchu także: J.C. Joerden, Medizinstrafrecht - Einführung, (w:) J.C. Joerden, A.J. Szwarc, K. Yamanaka (red.), Das vierte deutsch - japanisch - polnische Strafrechtskolloqium der Alexander von Humboldt - Stiftung, Poznań 2011, s. 145.

7 Por. M. Boratyńska, Szczepienia ochronne małoletnich a wykonywanie władzy rodzicielskiej. Uwagi na tle wyroku NSA, „Prawo i Medycyna” 2013, nr 3-4, s. 88; T. Dukiet-Nagórska, Uwagi na temat Ustawy z dnia 6 września 2001 r. o chorobach zakaźnych i zakażeniach, „Prawo i Medycyna” 2002, nr 11, s. 26.

8 Por. Reforma prawa o postępowaniu administracyjnym. Raport zespołu eksperckiego, Warszawa 2016, passim; dostęp: http://www.nsa.gov.pl/wydarzenia-wizyty-konferencje/uzupelniony-raport-ekspercki-nt-reforma-prawa-o-postepowaniu-administracyjnym,news,24,327.php. 
cesowych aspektów postępowania wobec pacjenta, ze szczególnym uwzględnieniem prawnych form działalności administracji publicznej ${ }^{9}$.

Sfera praw pacjenta ${ }^{10} \mathrm{w}$ ujęciu systemowym doznaje potencjalnej limitacji jako następstwo zastosowania administracyjnoprawnych środków oddziaływania wobec jednostki w wielu przypadkach ${ }^{11}$. Jakkolwiek jedna $\mathrm{z}$ możliwych do analizy płaszczyzn owej ingerencji jawi się jako szczególnie istotna dla ochrony praw pacjenta. Jest nią administracyjny przymus leczenia jako następstwo procesu decyzyjnego ${ }^{12}$ organów administrujących. Niewątpliwie do kanonu praw pacjenta przynależy uprawnienie $^{13}$ do wyrażenia zgody na interwencje medyczne. $Z$ jednej strony stanowi ono deklarację poszanowania przez państwo godności i integralności fizycznej każdej jednostki ${ }^{14}$ oraz prywatności ${ }^{15}$, z drugiej zaś kreuje element szczególnej więzi opartej na zaufaniu pomiędzy pacjentem a lekarzem ${ }^{16}$. Państwo, realizując swoje reglamentacyjne funkcje, posługuje się właściwymi środkami oddziaływania m.in. dla celów zachowania porządku, bezpieczeństwa czy też zdrowia publicznego. Działalność organów administrujących zdeterminowana wskazanym celem określana jest mianem policji ${ }^{17}$. Realizacja przydanych organom policyjnym kompetencji może in concreto implikować ingerencję w sferę praw i wolności jednostki. Egzemplifikację owego oddziaływania stanowi dopuszczalność ograniczenia samostanowienia jednostek w obliczu pożądanej ze społecznego ${ }^{18}$ punktu widzenia ingerencji medycznej.

9 W szczególności zaś pominięte zostają sporne zagadnienia związane z możliwością ustalenia przynależności konkretnej formuły reglamentacyjnej do jednej z klasycznie wyodrębnionych gałęzi prawa; por. klasyfikacja procedur w ustawie z dnia 19 sierpnia 1994 r. o ochronie zdrowia psychicznego. Co do tego por. P. Wszołek, Kryteria wyodrębniania prawa administracyjnego, Warszawa 2016, passim.

10 Stąd też za nazbyt wąskie przyjdzie potraktować wyrażone w piśmiennictwie zapatrywanie jakoby obowiązek szczepienia stanowił li tylko „ograniczenie praw i wolności obywatelskich”; zob. tak I. Jaworska, Odmowa zaszczepienia dziecka i jej konsekwencje prawne, „Przegląd Prawa Publicznego” 2017, nr 3, s. 60-62. Jakkolwiek notoryjnym jest, że prawo do samostanowienia ma prawnokonstytucyjną proweniencję, to analiza administracyjnych środków oddziaływania na sferę praw pacjenta charakteryzuje się szeregiem osobliwości, których nie sposób prima facie pominąć. Tym samym ograniczenie analizy administracyjnego przymusu leczenia li tylko do problematyki praw i wolności konstytucyjnych stanowi uproszczoną formułę wykładniczą.

11 Wystarczy wskazać w tym miejscu na stricte administracyjnoprawną regulację stosunku pacjenta w ramach zakładu administracyjnego, jakim jest samodzielny publiczny zakład opieki zdrowotnej; por. na ten temat A. ZemkeGórecka, Status prawny samodzielnego publicznego zakładu opieki zdrowotnej i jego prywatyzacja, Warszawa 2010, passim.

12 Posłużenie się nieprecyzyjnym sformułowaniem odwołującym się do jednej z prawnych form działalności administracji publicznej, jaką jest decyzja administracyjna, stanowi konieczne uproszczenie. Poprzez proces decyzyjny będziemy rozumieć te wszystkie przypadki, w których organ administracji publicznej w sposób sformalizowany ingeruje bezpośrednio w sferę praw pacjenta. Pojęciem tym na potrzeby niniejszego artykułu objęte zostaną zarówno decyzje administracyjne, jak również administracyjne tytuły wykonawcze.

13 Por. A. Augustynowicz, A. Czerw, Stosowanie środków przymusu bezpośredniego przez personel medyczny w procesie diagnostyczno-terapeutycznym w podmiotach leczniczych innych niż szpitale psychiatryczne - zagadnienia wybrane, „Prawo i Medycyna” 2013, nr 1-2, s. 35.

14 Por. D. Karkowska, Prawa pacjenta, Warszawa 2009, s. 126, 385.

15 Por. M. Świderska, Przymus leczenia i innych zabiegów medycznych, „Prawo i Medycyna” 2004, nr 3, s. 27-29.

16 W literaturze wskazuje się, iż wymóg zgody kreuje partnerską relację pomiędzy pacjentem a lekarzem; por. M. Filar, Postępowanie lecznicze (świadczenie zdrowotne) w stosunku do pacjenta niezdolnego do zgody, „Prawo i Medycyna" 2003, nr 5, s. 41.

17 Por. J. Dobkowski, Policja administracyjna. Zagadnienia doktrynalno-instytucjonalne, „Samorząd Terytorialny” 2004, nr 7-8, s. 9-11.

18 Zgoda pacjenta jako kategoria pozostająca w łączności z interesem społecznym była już przed laty analizowana w literaturze; zob. M. Sośniak, Z problematyki zgody chorego na poddanie się zabiegowi leczniczemu, „Polski Ty- 
Problematyka ta pozostaje $\mathrm{w}$ silnej korelacji z formami przymusowego wykonania obowiązków pozostających we właściwości organów administracji publicznej.

Pośród potencjalnych źródeł przymusu leczenia wskazuje się w szczególności na dwa hipotetyczne stany faktyczne uzasadniające jego aktualizację. Są nimi szeroko pojęte zdrowie psychiczne oraz zagrożenie epidemiologiczne ${ }^{19}$. Pierwsza ze wskazanych sfer ingerencji cechuje się złożonym charakterem oraz silną sądową ochroną praw jednostki. Zabezpieczenie praw pacjenta w tym przypadku wydaje się być optymalne ${ }^{20}$. W szczególności zaś szczególna rola sądu oraz proceduralne gwarancje pozwalają domniemywać ${ }^{21}$, iż pomimo intensywnej limitacji prawa do samostanowienia jednostki zachowany jest minimalny standard przepisany tak krajowymi, jak i międzynarodowymi regulacjami ${ }^{22}$. Z tych też przyczyn, jak również wobec bogatej literatury odnoszącej się do kontroli legalności stosowanych środków na gruncie ustawy psychiatrycznej kwestia ta nie wymaga dodatkowej analizy bez uciekania się do zbędnych powtórzeń. Co więcej, zabiegi kwalifikacyjne odnoszone do przedmiotowego trybu postępowania budzą wątpliwości. Nie bez racji można byłoby doszukiwać się w działaniach legitymowanych, oficjalnych podmiotów inicjujących poszczególne postępowania elementów prawnoadministracyjnych ${ }^{23}$. Niemniej jednak zagadnienie to jako przenoszące ramy niniejszego opracowania może być jedynie zasygnalizowane.

Zasadnicza część wywodu zostanie poświęcona drugiej grupie postępowań, a mianowicie związanych z zapobieganiem i zwalczaniem chorób zakaźnych ${ }^{24}$. Ponad

godnik Lekarski" 1960, nr 46, s. 1784 oraz projektu ustawy o ochronie zdrowia psychicznego), „Postępy Psychiatrii i Neurologii” 1993, z. 2, s. 311; A. Augustynowicz, A. Czerw, Stosowanie środków..., op. cit., s. 36; M. Filar, Postępowanie lecznicze..., op. cit., s. 44. Kwestie definicyjne zdrowia psychicznego, zaburzeń oraz innych stanów wymagających asystencji lekarskiej por. K. Dąbrowski, (w:) K. Dąbrowski (red.), Zdrowie psychiczne, Warszawa 1985, s. 8 i n.

20 Niemniej jednak z procesowego punktu widzenia sądowa kontrola stosowania przymusu psychiatrycznego może budzić wątpliwości. W piśmiennictwie wskazuje się na nieefektywność i ograniczoną skuteczność sądowych instrumentów ochronnych w owym zakresie; zob. jeden zamiast wielu K. Michalak, J.G. Firlus, Wybrane aspekty sądowej kontroli stosowania przymusu leczenia - przegląd zagadnień ze szczególnym uwzględnieniem szybkości postępowania, „Jurysta” 2016, nr 9, s. 16-17 oraz przytoczona tam literatura.

21 Choć w zakresie poszczególnych rozwiązań ustrojowych oraz proceduralnych odnoszących się do postępowania przed sądem opiekuńczym zostały w piśmiennictwie sformułowane krytyczne uwagi; por. J. Nelken, O konieczności kontroli sądowej nad przymusowym umieszczeniem w szpitalu psychiatrycznym, „Nowe Prawo” 1983, nr 3, s. 77-78.

22 Por. M. Balicki, Przymus w psychiatrii - regulacje i praktyka, „Prawo i Medycyna” 1999, nr 1, s. 42; K. Korzan, Postępowanie w sprawach ochrony zdrowia psychicznego, „Rejent” 1996, nr 6, s. 23-24.

23 Analiza piśmiennictwa zdaje się uzasadniać po części tę tezę. Zauważmy przeto, że również rola sądu oraz sędziego na gruncie ustawy psychiatrycznej pozostaje niedookreślona, a charakter niektórych czynności zdaje się być graniczny. Por. rozważania dotyczące prawnej formy działania sędziego wizytującego szpital psychiatryczny M. Sychowicz, Postępowanie sądowe w sprawach z ustawy o ochronie zdrowia psychicznego, „Przegląd Sądowy" 1995, nr 1, s. 7.

24 Postępowanie w przedmiotowej kategorii spraw regulowane jest przede wszystkim ustawą z dnia 5 grudnia 2008 r. o zapobieganiu i zwalczaniu zakażeń i chorób zakaźnych u ludzi (tekst jedn. z 2013 r. poz. 947, cyt. dalej: „ustawa epidemiologiczna”). Jakkolwiek aktualne pozostają również nawiązania do ustawy z dnia 14 marca 1985 r. o Państwowej Inspekcji Sanitarnej (tekst jedn. z 2015 r. poz. 1412, cyt. dalej: „uPIS”) co najmniej z dwu przyczyn. Po pierwsze, stanowi ona podstawowe źródło kreujące zadaniowy zakres działalności policji sanitarnej. Po drugie, wobec nadal aktualnych wątpliwości w zakresie ustalenia właściwej prawnej formy nakładania 
wszelką wątpliwość prawne środki ingerencji w sferę autonomii pacjenta mają w tym przypadku administracyjnoprawny charakter. Podstawowe $\mathrm{w}$ tym względzie pozostaje pytanie czy ustawodawca dokonał normatywnej korelacji postępowania o stricte administracyjnoprawnym charakterze do złożonej problematyki praw pacjenta. Innymi słowy, czy ustawy regulujące postępowanie przed organami policji sanitarnej oraz znajdujące subsydiarnie ${ }^{25}$ zastosowanie przepisy ogólnego postępowania administracyjnego ${ }^{26}$ realizują standard poszanowania praw pacjenta ${ }^{27}$ ?

\section{Formy prawne „konkretyzacji” obowiązków limitujących autonomię pacjenta $\mathrm{w}$ prawie administracyjnym}

Rozważania odnoszone do zakresu oraz stopnia zintensyfikowania ingerencji administracji publicznej wobec jednostki wydają się być niekompletne w braku oceny normatywnego modelu prawnych form komunikowania woli organu ${ }^{28}$. Podlegający ocenie w ramach niniejszego artykułu problem zdaje się sprowadzać do próby udzielenia odpowiedzi na pytanie, jaka prawna forma działania administracji publicznej $^{29}$ (policji sanitarnej) w omawianych przypadkach byłaby optymalna? $\mathrm{Na}$ tak postawione pytanie de lege lata nie sposób udzielić jednoznacznej odpowiedzi. Ustawodawca różnicuje bowiem prawnoprocesową formułę w zależności od treści i rodzaju obowiązku ${ }^{30}$ nakładanego na jednostkę. Z jednej strony, w przypadkach opisanych w art. 33 ustawy epidemiologicznej zamieszczona została norma kompetencyjna obligująca organ do wydania decyzji administracyjnej wobec aktualizacji

wybranych obowiązków uzasadnione jawi się subsydiarne odwołanie do tych przypadków w uPIS, gdzie ustawodawca wypowiada się explicite, co do orzeczenia form komunikowania woli organu administrującego.

Wobec zjawiska dekodyfikacji postępowania administracyjnego nie budzi wątpliwości, że postępowanie w sprawie przymusowego leczenia i badania mającego na celu zapobieżenie zagrożeniu epidemiologicznemu zaliczyć należy do grupy postępowań administracyjnych odrębnych (szczególnych); por. na temat problematyki systemu postępowań administracyjnych T. Woś, (w:) T. Woś (red.), H. Knysiak-Molczyk, A. Krawiec, M. Kamiński, T. Kiełkowski, Postępowanie administracyjne, Warszawa 2013, s. 85-88; Z. Kmieciak, Zarys teorii postępowania administracyjnego, Warszawa 2014, s. 69 i n.

26 Podstawowym aktem regulującym ogólne postępowanie administracyjne (jurysdykcyjne) jest ustawa z dnia 14 czerwca 1960 r. Kodeks postępowania administracyjnego (tekst jedn. Dz.U. z 2016 r. poz. 23 cyt. dalej jako: „k.p.a.”).

27 Pytanie to pozostaje aktualne jedynie w tych przypadkach, kiedy znajduje zastosowanie k.p.a. W pozostałych przypadkach - w braku sformalizowanego postępowania zmierzającego do konkretyzacji normy prawa materialnego - ochrona praw jednostki wyczerpywać się będzie w sądowej kontroli administracji publicznej, wykonywanej przez sądy administracyjne oraz w wewnątrzadministracyjnych procedurach kontrolnych przepisanych w postępowaniu egzekucyjnym.

28 Por. w tym duchu J. Boć, Obywatel wobec ingerencji współczesnej administracji, Wrocław 1985, s. 115.

29 Por. na temat ustalenia desygnatu pojęcia prawnych form działania administracji publicznej, jak również ich funkcji J. Starościak, Prawne formy i metody działania administracji, (w:) System prawa administracyjnego, t. 3, Wrocław-Warszawa-Kraków-Gdańsk 1978, s. 39-41. Przeglądu prawnych form działania policji sanitarnej dokonuje M. Janik, Policja sanitarna, Warszawa 2012, s. 172 i n.

30 W piśmiennictwie wskazuje się, iż jednym z aksjomatów (osobliwości i swoistości) prawa administracyjnego jest dualizm jego norm, zakładający dychotomiczny ich podział przy uwzględnieniu kryterium oddziaływania na sferę praw i obowiązków jednostki; zob. J. Zimmermann, Aksjomaty prawa administracyjnego, Warszawa 2013, s. 135136. Notoryjnym jest bowiem, że nie wszystkie normy konstytuujące obowiązki o administracyjnoprawnej proweniencji wymagają autorytatywnej konkretyzacji. 
administracyjnoprawnego stanu faktycznego. Niemniej jednak trudno dowodzić jakoby w omawianych przypadkach można było mówić o domniemaniu prawnej formy decyzji administracyjnej ${ }^{31}$, jako właściwej dla przymusu leczenia. Ustawowy katalog ma bowiem charakter zamknięty ${ }^{32}$, ergo nie może podlegać ekstensywnej wykładni. Z drugiej strony, pozostaje kwestia obowiązkowych szczepień ochronnych, o których mowa w art. 17 ustawy epidemiologicznej. De lege lata konsekwentnie przyjmuje się, że powinność realizacji tego obowiązku wynika wprost z przepisów prawa ${ }^{33}$, a tym samym wydanie decyzji administracyjnej w tym przedmiocie jest niedopuszczalne ${ }^{34}$. Merytoryczna poprawność oraz celowość zaprowadzonego przez ustawodawcę podziału budzi uzasadnione wątpliwości. Normatywna dyferencjacja metod „konkretyzacji” 35 obowiązków związanych z eliminowaniem zagrożenia epidemiologicznego niechybnie skutkuje dalszymi modyfikacjami odnoszonymi do trybu weryfikacji działań policji sanitarnej podejmowanych wobec jednostki.

Przyjrzyjmy się zatem pokrótce proceduralnym aspektom realizacji obowiązku poddania się obowiązkowym szczepieniom ochronnym. Przyjęta przez ustawodawcę konstrukcja przedmiotowego nakazu jest szczególna co najmniej z dwu przyczyn. Po pierwsze, w takiej sytuacji zbędny jest etap konkretyzacji normy prawa materialnego $^{36}$ (normy niekonkretyzowalne, bezpośrednio skuteczne) ${ }^{37}$. Tym samym brak jest tutaj sformalizowanego aktu administracyjnego precyzującego treść i adresata obowiązku. Sui generis doprecyzowanie obu relewantnych elementów obowiązku ma

31 W doktrynie wielokrotnie wysławiana była teza o istnieniu domniemania formy decyzji administracyjnej dla tych przypadków, kiedy organ administracji publicznej nakłada na jednostkę obowiązki, względnie pozbawia ją uprawnień; zob. M. Romańska, Komentarz do art. 104 Kodeksu postępowania administracyjnego, (w:) H. Knysiak-Molczyk (red.), Kodeks postępowania administracyjnego. Komentarz, Teza 5, Lex Omega; J. Jendrośka, Potrzeba nowego modelu procedury prawnej w administracji, „Państwo i Prawo” 2003, z. 3, s. 30. Niemniej jednak nawet wobec szczególnych zasad wprowadzania przymusu leczenia o charakterze administracyjnoprawnym nie sposób wykazywać jakoby bezwzględnie organ musiał dokonywać konkretyzacji obowiązków w formie decyzji administracyjnej. Art. 33 ustawy epidemiologicznej w sposób wyraźny wskazuje elementy administracyjnego stanu faktycznego, które uprawniają, a zarazem zobowiązują organ policji sanitarnej do wydania indywidualnego aktu administracyjnego. Odrębną kwestią pozostaje celowość wykorzystania tej formy prawnej komunikowania woli organu.

32 Por. w tym duchu na gruncie uprzednio obowiązującego stanu prawnego M. Świderska, Zgoda pacjenta na zabieg medyczny, Toruń 2007, s. 289; T. Dukiet-Nagórska, Uwagi..., op. cit., s. 25.

33 Por. również I. Jaworska, Odmowa..., op. cit., s. 62.

34 Por. P. Daniel, Egzekucja obowiązku poddania małoletniego dziecka szczepieniu ochronnemu w orzecznictwie sądów administracyjnych, „Przegląd Prawa Publicznego” 2014, nr 4, s. 48; wyrok WSA w Bydgoszczy z dnia 4 listopada 2015 r., II SA/Bd 871/15, Lex nr 1948739. Tym samym za błędne należy uznać wywody M. Janika, który to stwierdza, iż obowiązek poddania się szczepieniom ochronnym doznaje konkretyzacji w decyzji administracyjnej; por. M. Janik, Policja..., op. cit., s. 186-187.

35 Nawiązanie w tym miejscu do „konkretyzacji” obowiązku stanowi uproszczenie. Nie sposób tej formuły utożsamiać z etapami stosowania prawa przez organy administracji publicznej. Owa odmienna formuła konkretyzowania obowiązku sprowadza się zazwyczaj do indywidualizacji adresata ustawowego nakazu.

36 Por. D.R. Kijowski, (w:) D.R. Kijowski (red.), Ustawa o postępowaniu egzekucyjnym w administracji, Warszawa 2015, s. 163.

37 Por. T. Woś, (w:) T. Woś (red.), H. Knysiak-Molczyk, A. Krawiec, M. Kamiński, T. Kiełkowski, op. cit., s. 45. Tą metodę nakładania na jednostki obowiązków należy odróżnić od sytuacji, kiedy nakaz określonego postępowania wynika z tzw. czynności materialno-technicznych organów. Te ostatnie określane są również mianem aktów kreujących obowiązki w sposób szczególny; por. K.M. Ziemski, Ogólna charakterystyka działań (czynności) materialno-technicznych, (w:) R. Hauser, Z. Niewiadomski, A. Wróbel (współred.), System prawa administracyjnego, t. 5, Warszawa 2013, s. 71-72. 
miejsce dopiero w administracyjnym tytule wykonawczym. Organ administracji publicznej nie podejmuje uprzednio żadnych czynności składających się na akt procesowy ${ }^{38}$. Po drugie, organ policji sanitarnej powinien wykazywać dbałość o wykonanie nałożonego przez ustawodawcę obowiązku, tj. kontroluje jego prawidłowe wykonanie przez jednostkę 39 . W rezultacie, przy obowiązku wynikającym wprost z przepisów ustawy to prawodawca w sposób jednoznaczny rozstrzyga konflikt pomiędzy wartościami, jakimi są potencjalne zagrożenie dla zdrowia publicznego oraz prawo jednostki do samostanowienia. Zabezpieczenie wykonania ustawowego obowiązku poddania się szczepieniu ochronnemu następuje w trybie egzekucyjnego postępowania administracyjnego ${ }^{40}$. Niemniej jednak odejście od sformalizowanych trybów konkretyzacji obowiązku poddania się zabiegowi medycznemu nie oznacza, że jednostka zostaje pozbawiona możliwości obrony swoich praw ${ }^{41}$. W dalszej części artykułu ograniczymy się do analizy środków służących realizacji obowiązku szczepienia ochronnego małoletniego ${ }^{42}$. Przeprowadzona analiza umożliwi sformułowanie postulatów w płaszczyźnie lex ferenda.

\section{Obowiązkowe szczepienia ochronne - etap realizacji norm prawa administracyjnego (obowiązki administracyjnoprawne ipso iure)}

Niewykonanie w terminie przez zobowiązanego obowiązku, o którym mowa $\mathrm{w}$ art. 17 ustawy epidemiologicznej, aktualizuje po stronie wierzyciela administracyjnego konieczność podjęcia przepisanych prawem czynności zmierzających do zastosowania środków egzekucyjnych ${ }^{43}$. Realizacja obowiązków, tak wierzyciela, jak również organu egzekucyjnego została w płaszczyźnie normatywnej zabezpieczona poprzez przydanie możliwości kwestionowania stanu ich bezczynności ${ }^{44}$. Przy

Należy mieć na uwadze szczególną kategorię innych aktów i czynności z zakresu administracji publicznej, które również wydawane są poza sformalizowanym postępowaniem administracyjnym. Niemniej jednak nie sposób omawianego w tym miejscu przypadku zaliczyć do tej kategorii prawnych form działania administracji publicznej; por. na temat innych aktów i czynności A. Kisielewicz, Akty i czynności, o których mowa w art. $3 \S 2$ pkt 4 ustawy z 30 sierpnia 2002 r. - Prawo o postępowaniu przed sądami administracyjnymi, (w:) J. Posłuszny, Z. Czarnik, R. Sawuła (współred.), Instytucje procesu administracyjnego i sądowoadministracyjnego, Przemyśl-Rzeszów 2009.

39 Por. T. Woś, (w:) T. Woś (red.), H. Knysiak-Molczyk, A. Krawiec, M. Kamiński, T. Kiełkowski, Postępowanie..., op. cit., s. 45; J. Boć, Obywatel..., op. cit., s. 60-61.

40 Tj. w trybie i na zasadach określonych w ustawie z dnia 17 czerwca 1966 r. o postępowaniu egzekucyjnym w administracji (tekst jedn. Dz.U. z 2014 r. poz. 1619 ze zm.), cyt. dalej: „ustawa egzekucyjna”.

41 Już samo administracyjne postępowanie egzekucyjne z założenia służy ochronie praw jednostki.

42 Celem uproszczenia wywodu czynimy założenie, iż małoletni będący pośrednim adresatem działań organu policji sanitarnej nie ukończył 6. roku życia.

43 Organ administracji publicznej występujący w roli wierzyciela ma obowiązek doprowadzenia do przekształcenia stanu rzeczywistego (zastanego) do stanu określonego treścią zakazu ustawowego; por. co do znaczenia sformułowanej w art. $6 \S 1$ ustawy egzekucyjnej dyrektywy postępowania, wyrok WSA w Gliwicach z dnia 29 maja 2013 r., I SA/GI 146/13, Lex nr 1346882.

44 Por. na temat doniosłości środka prawnego, o którym mowa w art. 6 § 1a ustawy egzekucyjnej M. Mikosz, Konstrukcja i rozpoznawanie środków zaskarżenia bezczynności w ustawie o postępowaniu egzekucyjnym w administracji, „Samorząd Terytorialny” 2007, nr 7-8, s. 129-132. 
czym, co istotne, ustawodawca w sposób bez mała osobliwy konstruuje legitymację do wniesienia skargi służącej kwestionowaniu przewłoki w przymusowym postępowaniu administracyjnym. Odnotować należy, iż uprawnionym do wniesienia środka prawnego $\mathrm{z}$ art. $6 \$$ la ustawy egzekucyjnej jest również podmiot, którego legitymacja oparta jest wyłącznie na dążności do zabezpieczenia interesu faktycznego. Jest to sytuacja o tyle szczególna, że z zasady obiektywny porządek prawny w szczególności zaś ogólne postępowanie administracyjne, kreują środki służące ochronie uzasadnionego interesu prawnego ${ }^{45}$ jednostki $^{46}$. Odnotujmy, iż w przypadku sprowadzenia realizacji obowiązku szczepienia ochronnego małoletniego katalog podmiotów potencjalnie legitymowanych do wniesienia skargi na bezczynność może być nader szeroki. Jak się wydaje, zakresem podmiotowym legitymacji do wniesienia omawianego środka prawnego można objąć kierującego zakładem administracyjnym, do którego małoletni uczęszcza, np. przedszkola ${ }^{47}$.

Poza aspektem praktycznym zabezpieczenia efektywności postępowania egzekucyjnego wypada zwrócić uwagę na ważki element o prawnej proweniencji, wynikający z treści art. $6 \$ 1$ u ustawy egzekucyjnej. Skarga na bezczynność wierzyciela umożliwia przeprowadzenie wstępnej kontroli dopuszczalność wszczęcia i prowadzenia postępowania egzekucyjnego. Notoryjnym jest, że negatywną przesłankę realizacji ustawowego obowiązku - w tym również postępowania egzekucyjnego ze względu na niewymagalność nakazu - stanowią długotrwałe zdrowotne przeciwwskazania szczepienia dziecka ${ }^{48}$. Wniesienie skargi na bezczynność wierzyciela pozwala na zweryfikowanie także tej okoliczności. Wierzyciel nie pozostaje w stanie bezczynności w razie niedopuszczalności egzekwowania obowiązku. Co istotne, podmiot kwestionujący inercję wierzyciela administracyjnego może zainicjować również sądową kontrolę legalności postępowania organu odpowiedzialnego za wykonanie obowiązku szczepienia ochronnego.

45 Por. co do sposobu rozumienia i źródeł interesu prawnego na gruncie ogólnego postępowania administracyjnego R. Kędziora, Kodeks postępowania administracyjnego. Komentarz, Warszawa 2014, s. 248-249.

46 Por. K. Jandy-Jendrośka, J. Jendrośka, System jurysdykcyjnego postępowania administracyjnego, (w:) System prawa administracyjnego, t. 3, s. 189: „Kodeks oparł koncepcję strony na dwóch równorzędnych sprawdzianach - na obowiązku prawnym i prawnie chronionym interesie (...)".

47 W kontekście problematycznego zagadnienia związanego $z$ dopuszczalnością odmowy przyjęcia małoletniego do zakładu administracyjnego wobec stwierdzenia braku zrealizowania obowiązku szczepienia, środek prawny przewidziany w art. 6 § 1a ustawy egzekucyjnej jawi się jako szczególnie przydatny. Por. na temat korelacji obowiązku z art. 17 ustawy epidemiologicznej i dopuszczalności odmowy przyjęcia do przedszkola: Informacja o działalności Rzecznika Praw Dziecka za rok 2015 oraz uwagi o stanie przestrzegania praw dziecka, Warszawa 2016, s. 145; M. Boratyńska, op. cit., s. 79.

48 Por. P. Daniel, Egzekucja..., op. cit., s. 52; M. Boratyńska, Szczepienia..., op. cit., s. 75, gdzie wskazano na równorzędność obu obowiązków. Lekarskie badanie kwalifikacyjne uznać można wręcz na komplementarny składnik ogólnego ustawowego obowiązku poddania się szczepieniom ochronnym. Na marginesie zaznaczyć wypada, iż przeciwwskazania medyczne stanowią in genere negatywną przesłankę stosowania przymusu w ogólności; por. tak J. Sawicki, Przymus leczenia, eksperyment, udzielenie pomocy i przeszczep w świetle prawa, Warszawa 1966, s. 82. 
Tym samym w sytuacji braku przeciwwskazań medycznych oraz przy założeniu realizacji przez lekarza obowiązków informacyjnych ${ }^{49}$, jak też w następstwie podjęcia przezeń ${ }^{50}$ czynności materialno-technicznej wezwania na badanie kwalifikacyjne wobec notyfikacji braku zgody podmiotu ${ }^{51}$, o którym mowa w art. 5 ust. 2 ustawy epidemiologicznej, na szczepienie ochronne, organ policji sanitarnej jest obowiązany do podjęcia pierwszych czynności regulowanych ustawą egzekucyjną. Przede wszystkim, zgodnie z zasadą zagrożenia, rolą organu jest doprowadzenie do wykonania obowiązku bez potrzeby stosowania środków egzekucyjnych ${ }^{52}$. Możliwość odstąpienia od stosowania przymusu państwowego jawi się jako szczególnie pożądana $\mathrm{w}$ omawianym przypadku³ ${ }^{53}$ Zagadnienie to pozostaje w łączności z prognozowaną skutecznością instrumentów oddziaływania organów egzekucyjnych na podmioty odpowiedzialne za wykonanie nakazu szczepienia ochronnego małoletniego.

Pośród dwóch potencjalnie dostępnych środków egzekucyjnych (grzywna w celu przymuszenia oraz przymus bezpośredni ${ }^{54}$ ) bez mała można zakładać uprzednią niecelowość ich stosowania ${ }^{55}$. Wysłowiona w tym miejscu teza zdaje się znajdować potwierdzenie w normatywnym kształcie obu sposobów egzekucji. Ustawodawca nakazuje organowi egzekucyjnemu stosować takie środki, które okażą się $\mathrm{z}$ jednej strony skuteczne, a z drugiej najmniej uciążliwe dla adresata obowiązku. Istotnie zatem w pierwszej kolejności oddziaływanie na odpowiedzialnego za wykonanie nakazu powinno odbywać się poprzez nałożenie grzywny w celu przymuszenia. Niemniej jednak nie sposób zgodzić się z tezą jakoby był to jedyny dostępny

49 Informacja i objaśnianie czynności leczniczych pozostają ze sobą w korelacji; por. A. Górski, O obowiązku lekarza poinformowania pacjenta o zgodzie pacjenta na zabieg, „Studia luridica” 2001, t. XXXIX, s. 85; Tenże: czynność lecznicza i czynność nielecznicza (w:) A. Górski (red.), op. cit., s. 13-18, por. także przywoływaną tam literaturę zagadnienia. Również: R. Kędziora, Problematyka zgody pacjenta w świetle polskiego ustawodawstwa medycznego, „Prokuratura i Prawo” 2003, nr 7-8, s. 57. W literaturze wskazano, iż ustawodawca w przypadku nakazu poddania się obowiązkowi szczepienia ochronnego szczególną uwagę poświęca obowiązkowi informowania pacjenta o istnieniu i treści obowiązku; zob. A. Augustynowicz, A. Czerw, Stosowanie..., op. cit., s. 37. Odrębne i bardzo kontrowersyjne zagadnienie stanowi kwestia zakresu podmiotowego owego obowiązku informacyjnego związanego z obecnością rodzica przy szczepieniu małoletniego; por. R. Kubiak, Szczepienie dziecka bez obecności rodziców, „Medycyna Praktyczna”, dostęp: http://www.mp.pl/szczepienia/prawo/zapytajprawnika/71977,szczepienie-dziecka-bez-obecnosci-rodzicow (data dostępu: 15.09.2016 r.).

50 Zob. I. Jaworska, Odmowa..., op. cit., s. 64.

51 Użyta w tym przypadku liczba pojedyncza stanowi uproszczenie. Oczywistym jest, że zarówno upomnienie, jak również tytuł wykonawczy oraz czynny udział w postępowaniu egzekucyjnym dotyczy obojga prawnych opiekunów małoletniego. Tak w odniesieniu do rodziców wyrok WSA w Krakowie z dnia 25 października 2012 r., III SA/ Kr 1532/11, Lex nr 1235560.

52 Por. tak T. Lewandowski, Glosa do wyroku NSA z dnia 8 lipca 2009 r., II FSK 618/08, Teza nr 3, Lex/el 2011.

53 W przypadku niewykonania obowiązku szczepienia ochronnego mamy do czynienia z tzw. przymusem pośrednim. Jego istota sprowadza się do możliwości zastosowania sankcji o charakterze administracyjnym dla celów spowodowania wykonania nakazu, przy jednoczesnym wykluczeniu możliwości użycia przymusu w postaci siły fizycznej oraz innych form bezpośredniego oddziaływania na pacjenta; zob. co do definicji M. Świderska, Zgoda pacjenta..., op. cit., s. 248. Choć - jak się wydaje - sankcje administracyjne są tutaj nazbyt wąsko rozumiane. Nie sposób przyjmować bowiem, że przymus bezpośredni właściwy ustawie egzekucyjnej w administracji nie jest sankcją o charakterze prawnoadministracyjnym.

54 Por. tak również I. Jaworska, Odmowa..., op. cit., s. 70.

55 Por. co do ograniczonej skuteczności przymusu bezpośredniego administracyjnoprawnego A. Augustynowicz, A. Czerw, Stosowanie..., op. cit., s. 39-40. 
sposób egzekwowania obowiązku ${ }^{56}$. Organ egzekucyjny w swej działalności winien przy doborze i stosowaniu środków brać pod uwagę dyrektywę kierunkową, jaką jest cel postępowania egzekucyjnego, czyli przymusowa realizacja obowiązku ${ }^{57}$. $\mathrm{O}$ ile $\mathrm{w}$ omawianym przypadku wykluczone jest zastosowanie przymusu bezpośredniego, przewidzianego w art. 36 ustawy epidemiologicznej ${ }^{58}$, o tyle egzekwujący obowiązek ma możliwość przymusowego doprowadzenia tak odpowiedzialnego za wykonanie obowiązku, jak również małoletniego do miejsca wykonania świadczenia medycznego ${ }^{59}$.

Niemniej jednak brak jest de lege lata prawnych możliwości zastosowania przymusu bezpośredniego dla samej czynności wykonania szczepienia ochronnego. Stąd też jako szczególnie pożądane jawi się poszukiwanie alternatywnych, koncyliacyjnych form przekonywania zobowiązanego do dobrowolnego wykazania posłuchu dla normy prawa administracyjnego materialnego. Obowiązek skierowania do zobowiązanego upomnienia, o którym mowa w art. 15 ustawy egzekucyjnej, stanowi jedynie konieczny element formalny umożliwiający przejście do kolejnego etapu postępowania. Również swoiste novum normatywne, jakim są działania informacyjne ${ }^{60}$ podejmowane wobec zobowiązanego nie jawią się jako optymalna formuła dla możliwie szybkiego osiągnięcia celu w postaci realizacji obowiązku, o którym mowa w art. 17 ustawy epidemiologicznej. Stąd też można postulować wprowadzenie formuły mediacyjnego ${ }^{61}$

Część piśmiennictwa przyjmuje, że środki egzekucyjne mają służyć jedynie zdyscyplinowaniu prawnych opiekunów tak; np. P. Daniel, Egzekucja..., op. cit., s. 49; M. Świderska, Przymus leczenia..., op. cit., s. 26. Tym samym wykluczają prima facie stosowanie środków przymusu dostępnych w postępowaniu egzekucyjnym. Zdaje się, że w tym przypadku nie zostaje uwzględniona różnica pomiędzy zastosowaniem obu różnych w swym zakresie sposobów przymusu. Czym innym jest bowiem sprowadzenie wykonania obowiązku przymusem, a czym innym $\mathrm{np}$. doprowadzenie rodzica wraz z dzieckiem do miejsca realizacji obowiązku. Zob. także ogólne rozważania dotyczące „zmuszenia do badań” poprzez użycie przymusu bezpośredniego M. Świderska, Zgoda pacjenta..., op. cit., s. 289. T. Dukiet-Nagórska również podkreśla ową różnicę i wskazuje, że egzekutor administracyjny ma prawną możliwość doprowadzenia zobowiązanego do miejsca badania lub leczenia; zob. T. Dukiet-Nagórska, Uwagi..., op. cit., s. 26-27. Choć - co osobliwe - Autorka wyklucza jednocześnie dopuszczalność stosowania środków przymusu w sytuacji egzekwowania wykonania nakazu poddania się szczepieniu ochronnemu; por. ibidem, s. 29.

57 Por. w tym duchu M. Król, Szukanie złotego środka - o zasadzie stosowania egzekucji najmniej uciążliwej dla zobowiązanego, „Przegląd Podatkowy” 2015, nr 8, s. 42.

58 Por. A. Augustynowicz, I. Wrześniewska-Wal, Aspekty prawne obowiązkowych szczepień ochronnych u dzieci, „Pediatria Polska” 2013, nr 88, s. 124. Chociaż Autorki wykluczają in genere stosowanie przymusu w omawianym zakresie, zarówno tego z ustawy epidemiologicznej, jak również przymusu jako środka egzekwowania obowiązków przez egzekutora; ibidem, s. 125.

59 Zastosowanie przymusu wobec małoletniego jest możliwe z uwzględnieniem treści art. 152 ustawy egzekucyjnej. Należy mieć na względzie, iż zobowiązanym w postępowaniu egzekucyjnym są rodzice (przedstawiciele ustawowi), natomiast podmiotem wykonawczym jest małoletni. Stąd też istnieje także możliwość doprowadzenia rodziców do miejsca wykonania badania kwalifikacyjnego wraz z dzieckiem. Ostatnia teza jest uzasadniona przy założeniu komplementarności obowiązku szczepienia oraz badań kwalifikacyjnych - o czym również powyżej.

60 Por. art. $6 \S 1 \mathrm{~b}$ ustawy egzekucyjnej. Zaznaczany jedynie uprzednią nieprzydatność owego trybu z uwzględnieniem lokacji i systemowych jego powiązań z egzekwowaniem obowiązków o charakterze pieniężnym.

61 Problematyka tzw. mediacji administracyjnej przynależy do zagadnień spornych w polskim piśmiennictwie; zob. na ten temat A. Szpor, Mediacja w prawie administracyjnym, (w:) E. Gmurzyńska, R. Morek (współred.), Mediacje. Teoria i praktyka, Warszawa 2014, s. 397 i n.; J. Wegner-Kowalska, Idea mediacji w postępowaniu administracyjnym, „Przegląd Prawa Publicznego” 2016, nr 10, s. 90-92. Niemniej jednak ostatnia modyfikacja procesowych ram jurysdykcji administracyjnej (zob. ustawa z dnia 7 kwietnia 2017 r. o zmianie ustawy - Kodeks postępowania administracyjnego oraz niektórych innych ustaw) zdaje się zamykać przedmiotowy rozdział dyskursu naukowego. Ustawodawca, wiedziony potrzebą uelastycznienia działalności administracji publicznej oraz 
przedegzekucyjnego ${ }^{62}$ sposobu likwidacji sporu. Niewątpliwie zobowiązany jest wielokrotnie informowany o konieczności realizacji nałożonego przez ustawodawcę obowiązku, m.in. przez lekarza ${ }^{63}$, ale możliwe, że dopiero udział osoby trzeciej (mediatora) spowoduje dobrowolne wykonanie obowiązku ${ }^{64}$. Potrzeba wprowadzenia skutecznych i elastycznych instrumentów procesowych jest szczególnie pożądana w obliczu ograniczonej efektywności egzekucji administracyjnej oraz szczególnej sfery oddziaływania administracji publicznej, jaką jest autonomia pacjenta. Mediacja jawi się jako odformalizowane i elastyczne postępowanie niepodlegające szczegółowej reglamentacji ${ }^{65}$. Tym samym stwarza odpowiednie warunki dla konsensu ${ }^{66}$. Oczywiście, specyfika norm prawa administracyjnego (ius cogens) oraz immanentnie władczy, względnie jednostronny charakter ingerencji w sferę praw i wolności zdaje się nie przystawać do formuły polegającej na negocjowaniu i przekonywaniu adresata nakazu do jego dobrowolnego wykonania ${ }^{67}$. Przytoczone osobliwości prima facie wykluczają zatem dopuszczalność nieformalnych „pertraktacji” w tym zakresie ${ }^{68}$. Niemniej jednak w obliczu ograniczonej skuteczności dostępnych de lege lata środków, bez konieczności uciekania się do wykładni contra legem ${ }^{69}$ oraz przy jednoczesnym poszanowaniu prawa do samostanowienia należy poszukiwać alternatywnych form egzekwowania ustawowych obowiązków. Co więcej, dialog adresata nakazu ustawowego oraz organu administracji publicznej odpowiedzialnego za jego wykonanie odbywa się wyłącznie w sformalizowanych postępowaniach kontrolnych wewnątrzadministracyjnych, tj. w postępowaniu

zapewnienia przyjaznego (client friendly) i odformalizowanego podejścia wobec podmiotów zewnętrznych (jednostki), wprowadził w art. 96a i n. k.p.a. instytucję mediacji do postępowania administracyjnego. Równoległe dokonano rewizji zasady ogólnej postępowania administracyjnego zadekretowanej z art. 13 k.p.a., czyniąc organ prowadzący postępowanie administracyjne odpowiedzialnym nie tylko (jak to miało miejsce w stanie prawnym do 1 czerwca 2017 r.) za dążenie do ugodowego załatwienia sprawy, lecz przede wszystkim stworzenie właściwych ram dla dialogu pomiędzy jednostką a administracją publiczną.

62 Pewne wątpliwości implikować może właściwa podstawa prawna upoważnienia organu egzekucyjnego do przeprowadzenia mediacji. Jak się wydaje - z pewną dozą ostrożności - może w omawianym przypadku znaleźć zastosowanie art. 18 ustawy egzekucyjnej zawierający klauzulę subsydiarnego stosowania przepisów k.p.a. Przy czym jednoczesnego podkreślenia wymaga fakt, iż mutatywne stosowanie przepisów regulujących administracyjne postępowanie mediacyjne dozwala na wprowadzenie niezbędnych modyfikacji. Nade wszystko pożądanym jest ograniczenie formalizmu przedmiotowego trybu wpadkowego celem przyspieszenia postępowania. Zob. co do obowiązków informacyjnych lekarza oraz związania podmiotów świadczących usługi medyczne komunikatem w sprawie programu szczepień ochronnych I. Jaworska, op. cit., s. 63.

64 Zob. argumenty przemawiające za potrzebą inkorporowania instytucji mediacji do ogólnego postępowania administracyjnego; por. J. Wegner-Kowalska, Mediacja (art. 13, art. 96a-96g), (w:) Raport..., s. 96-97.

65 Por. Z. Kmieciak, Mediacja i koncyliacja w prawie administracyjnym, Kraków 2004, s. 56.

66 Podstawową funkcją mediatora jako bezstronnego uczestnika dialogu podmiotów partycypujących w postępowaniu zmierzającym do usunięcia faktycznego sporu jest inter alia facylitacja i usprawnienie bilateralnej komunikacji; zob. C.H. Moore, Mediacje. Praktyczne strategie rozwiązywania konfliktów, Warszawa 2012, s. 33-34.

67 Wprawdzie postępowanie administracyjne nie zostało oparte na konstrukcji sporu prawnego, a tym samym nie ma ono charakteru kontradyktoryjnego, to jego konfliktowy (adversarial) charakter nie budzi zasadniczych wątpliwości. Przedmiotową zależność zdaje się dostrzegać piśmiennictwo zagraniczne w szczególności zaś to odnoszone do amerykańskiej praktyki administracyjnej; zob. E. Rubin, It's time to Make the Administrative Procedure Act Administrative, „Cornel Law Review” 2003, vol. 89, s. 102-103.

68 Zob. krytyczne uwagi na temat instytucji mediacji w postępowaniu sądowo-administracyjnym: T. Woś, Postępowanie mediacyjne w ustawie - Prawo o postępowaniu przed sądami administracyjnymi, (w:) Podmioty administracji publicznej i prawne formy ich działania, Toruń 2005. Zob. A. Augustynowicz, A. Czerw, Stosowanie..., op. cit., s. 45, 48. 
zażaleniowym oraz procedurze zarzutów. Nie sposób kwalifikować tych incydentalnych postępowań jako formy wysłuchania adresata władczych działań administracji ${ }^{70}$.

Odrębną kwestię stanowi prakseologiczna i celowościowa dyrektywa odstąpienia od zastosowania danego sposobu egzekucji. W omawianym przypadku, pomimo normatywnej dopuszczalności sięgnięcia przez administracyjny organ egzekucyjny po konkretny środek egzekucyjny, społeczny aspekt wartościowań może uzasadniać negatywną ocenę przystąpienia do realizacji obowiązku w dany sposób, tj. przy wykorzystaniu konkretnego środka egzekucyjnego. Niemniej jednak rozważania te dotyczą sfery odstąpienia (wyboru) środka egzekucyjnego przez organ, a nie prawnej płaszczyzny jego zastosowania. Tym samym odnoszą się do sfery faktów a nie sfery prawa. W piśmiennictwie daje się niejednokrotnie odnotować błędne w swym założeniu podejście, zgodnie z którym obie wskazane w tym miejscu płaszczyzny, tj. aksjologicznych wartościowań oraz prawnej dopuszczalności, podlegają scaleniu ${ }^{71}$.

\section{W poszukiwaniu standardu due process $\mathrm{w}$ administracyjnych postępowaniach oddziałujących na sferę praw pacjenta - uwagi de lege ferenda}

Sygnalizowane powyżej niedostatki przyjętego modelu egzekwowania obowiązku z art. 17 ustawy epidemiologicznej czynią aktualnym konieczność rozważania jego zmiany. Przede wszystkim sam sposób „konkretyzacji” adresata oraz po części treści obowiązku może budzić wątpliwości ${ }^{72}$. Nie wydaje się jakoby przyjęta metoda regulacji była odpowiednia. Stąd też pod rozwagę ustawodawcy należy poddać możliwość przydania organom Państwowej Inspekcji Sanitarnej kompetencji do nakładania ${ }^{73} \mathrm{w}$ drodze decyzji administracyjnej wszelkich obowiązków ingerujących w sferę autonomii pacjenta. Nie ma bowiem dostatecznych argumentów uzasadnia-

Wysłuchanie adresata działań administracji publicznej traktowane jest, jako minimalny standard, jaki powinno zapewniać postępowanie administracyjne; por. Z. Kmieciak, Zarys teorii..., op. cit., s. 86.

71 Zdaje się umykać części piśmiennictwa okoliczność jaką jest brak wyraźnej podstawy prawnej kreującej negatywną przesłankę stosowania danego sposobu egzekucji wobec zobowiązanego - pacjenta. Niezależnie od wątpliwości, powodowanych przede wszystkim celowościową płaszczyzną wartościowań, nie sposób uznać za prawidłowe podejście zgodnie, z którym negatywna in concreto ocena zastosowania środka egzekucyjnego - np. z uwzględnieniem aspektu braku celowości zastosowania - ma w płaszczyźnie ogólnosystemowej skutkować jego niedopuszczalnością z mocy prawa.

72 W literaturze wskazano bowiem na niedostatki w zakresie doprecyzowania treści nakazu poddania się obowiązkowym szczepieniom ochronnym. Kwestia ta wykazuje również łączność z problematyką rangi aktu prawnego zawierającego subsydiarny element współkształtujący treść obowiązku stanowiącego podstawę stosowania przymusu administracyjnego; zob. A. Augustynowicz, I. Wrześniewska-Wal, Aspekty prawne..., op. cit., s. 121.W świetle wymogu wysokiego stopnia precyzyjności obowiązku wynikającego ex lege, a podlegającego egzekucji kwestia ta wydaje się być nader sporna; por. D.R. Kijowski, (w:) D.R. Kijowski (red.), Ustawa..., op. cit., s. 163, gdzie wskazano na konieczność niebudzącego wątpliwości ustalenia na podstawie przepisu kreującego nakaz tak adresata, jak również samą treść obowiązku. Stąd też nawet samo stwierdzenie istnienia obowiązku, tj. wydanie decyzji deklaratoryjnej, pozwalałoby wyeliminować wzmiankowane powyżej wątpliwości.

73 W ten sposób nie następuje transformacja charakteru obowiązku poddania się obowiązkowym szczepieniom ochronnym. Zważyć należy, iż forma prawna decyzji administracyjnej może jawić się jako optymalna również w przypadku potwierdzenia nakazu, tj. konieczności wykazania posłuchu dla administracyjnoprawnego obowiązku. Organ w takim przypadku jedynie stwierdza, że dany obowiązek wiąże dany podmiot, jednocześnie go 
jących odejście od stricte prawnoadministracyjnej formuły limitacji praw pacjenta. W szczególności zaś z uwzględnieniem dyrektyw optymalizacji czasu trwania postępowań $\mathrm{z}$ udziałem jednostki, jako niecelowe jawi się $\mathrm{w}$ tym zakresie przekazywanie stricte policyjnych kompetencji sądom powszechnym ${ }^{74}$.

Poza kwestią ujednolicenia prawnej formy działania organów administrujących konieczne są ustawowe zabiegi dostosowawcze w zakresie przebiegu postępowania. Jak się wydaje, formuła ogólnego postępowania administracyjnego w tym przypadku jawi się jako dalece nieodpowiednia. Stąd też implementacja na grunt ustawy epidemiologicznej idei postępowań hybrydowych stanowi pożądany zabieg ${ }^{75}$. Formuła ta umożliwia bowiem skorelowanie kwestii stricte publicznoprawnych (dbałość o zdrowie publiczne) z tymi o proweniencji zbliżonej do prawa prywatnego ${ }^{76}$. Co więcej, proponowane rozwiązanie stanowiłoby racjonalny kompromis pomiędzy pożądanym standardem ochrony osób partycypujących w postępowaniu przed organami policji sanitarnej a potrzebą zapewnienia efektywnych środków egzekwowania obowiązków nałożonych na jednostkę $e^{77}$ (optymalizacja interesu jednostkowego ze słusznym interesem społecznym).

Efekt ten możliwy jest do osiągnięcia poprzez wprowadzenie $\mathrm{zmian}^{78} \mathrm{w}$ kilku aspektach. Po pierwsze, ustawodawca winien przewidzieć możliwe krótkie terminy załatwiania spraw. Kategoria dóbr prawnych, których dotyczy postępowanie wymaga pełnej realizacji zasady szybkości postępowania ${ }^{79}$. Po drugie, należy dookre-

nie kreując; J. Zimmermann, Polska jurysdykcja administracyjna, Warszawa 1996, s. 141; J. Jendrośka, op. cit., s. 30 .

74 Przyjęta w ustawie epidemiologicznej formuła przymusu nie wymaga tak daleko idących proceduralnych gwarancji o charakterze ustrojowym. Por. co do konieczności wprowadzenia sądowej kontroli legalności przymusu leczenia psychiatrycznego J. Nelken, O konieczności..., op. cit., s. 74-75. Jak się wydaje w omawianym przypadku nie aktualizuje się niebezpieczeństwo nadużyć ze strony organów policji sanitarnej.

75 Por. w zakresie idei i modelu tej formuły procesowej Z. Kmieciak, Zarys teorii..., op. cit., s. 78.

76 Dyskutowane zagadnienia odnoszą się do braku zgody względnie wyrażenia sprzeciwu dla wykonania świadczenia medycznego. Nie sposób nie dostrzec dyskutowanej w orzecznictwie i literaturze złożonej i na poły mieszanej natury tego uprawnienia pacjenta; por. rozważania na ten temat J. Ciechorski, Glosa do wyroku Sądu Apelacyjnego w Katowicach z dnia 15 stycznia 2014 r., I ACa 922/13, „Orzecznictwo Sądów Polskich” 2016, nr 6, s. 781784. Nawiązanie do glosowanego judykatu nie jest przypadkowe. Sąd bowiem inter alia wskazuje na szczególny i niepoddający się jednoznacznej kwalifikacji charakter prawny zgody pacjenta. Stąd też przy postulowanej zmianie formuły postępowania należy mieć na uwadze specyfikę sfery, w którą to swoimi czynnościami zamierza ingerować administracja publiczna.

77 Normatywna metoda modyfikacji przebiegu postępowania (tzw. postępowania administracyjne szczególne) przed organem administracji publicznej nie zawsze w sposób całościowy uwzględnia interesy recypientów ingerencji państwa w sferę praw i wolności jednostki. Odnotujmy dla porządku rozważań, iż uzasadnieniem dla nowatorskich rozwiązań procesowych bywa potrzeba usprawnienia i operacjonalizacji działania organów administracji publicznej; zob. np. H. Knysiak-Sudyka, L. Klat-Wertelecka, Model administracyjnego postępowania uproszczonego, „Państwo i Prawo” 2016, z. 7, s. 93. Tym samym dyrektywa ustawodawcza obejmuje w tym przypadku nie stricte interesy stron postępowania, acz potrzebę globalnego usprawnienia funkcjonowania aparatu państwa, co dopiero w aspekcie pośredniego oddziaływania może w sposób pozytywny wpłynąć na ochronę praw strony.

78 Postulat odpowiednich zmian ustawowych w zakresie nakazu poddania się obowiązkowym szczepieniom ochronnym został już w literaturze wysłowiony; por. chociażby A. Augustynowicz, I. Wrześniewska-Wal, Aspekty prawne..., op. cit., s. 125.

79 Na gruncie ustawy psychiatrycznej ustawodawca wprowadza instrukcyjny 14-dniowy termin dla przeprowadzenia rozprawy. W piśmiennictwie zdaje się dominować pogląd o optymalnej formule temporalnej w tym zakresie; zob. L.K. Paprzycki, Ochrona praw człowieka w świetle projektu ustawy o ochronie zdrowia psychicznego (część II), „Palestra” 1993, nr 11, s. 27, który wskazał, iż miesięczny termin jawi się jako nazbyt długi. Odmiennie J. Nelken, op. cit., s. 77. Przy czym podkreślenia wymaga tutaj okoliczność, iż w przypadku postępowania przed organami 
ślić w drodze ustawowej sposób inicjowania postępowań w sprawach dotyczących przymusowego leczenia. De lege lata zdaje się, że postępowania, w wyniku których może zostać wydana decyzja administracyjna, o jakiej mowa w art. 33 ust. 1 ustawy epidemiologicznej, są wszczynane w trybie wnioskowym ${ }^{80}$. Jakkolwiek możliwa jest przeciwna argumentacja. W piśmiennictwie wskazuje się, że w zakresie wszczynania postępowania administracyjnego wbrew literalnej treści art. $61 \S 1$ k.p.a., brak jest normatywnej przemienności. Tym samym to przepisy prawa materialnego winny określać sposób inicjowania postępowania (wnioskowy bądź z urzędu) ${ }^{81}$. W szczególności zaś nierozstrzygnięta explicite w ustawie pozostaje kwestia związania organu zgłoszeniem dokonanym przez lekarza. Po trzecie, wobec braku w ogólnym postępowaniu administracyjnym instytucji prawa pomocy na potrzeby tego postępowania należy zapewnić udział profesjonalnego pełnomocnika $\mathrm{z}$ urzędu ${ }^{82}$. Uzasadnienia po temu należy upatrywać nie tylko w partykularnych interesach jednostki, ale również we względach ekonomii postępowania. Po czwarte, rozważyć należy dopuszczalność udziału w postępowaniu Rzecznika Praw Pacjenta jako podmiotu na prawach strony.

Oczywiście, wraz ze zmianami dotyczącymi przebiegu postępowania przed organem policji sanitarnej należy rozważyć potrzebę uściślenia trybu egzekwowania nałożonych obowiązków. Nader pożądanym rozwiązaniem jest ograniczenie dopuszczalności wielokrotnego nakładania grzywny w celu przymuszenia. Nie mniej istotna jest kwestia rozważenia zmiany przebiegu egzekucji dotyczącej obowiązków stricte związanych z autonomią pacjenta. W szczególności zaś jako niezbędne jawią się zmiany w zakresie udziału organów asystujących poprzez rozszerzenie katalogu podmiotowego o lekarza ${ }^{83}$. Wówczas lekarz jako aktywnie partycypujący w postępowaniu egzekucyjnym realizowałby czynności z zakresu administracji publicznej, które przyjmowałyby postać - znanych austriackiej praktyce ustrojowej ${ }^{84}$ - bezpośrednich

administracji publicznej ustawodawca winien przepisać termin dla załatwienia sprawy, a nie podjęcia poszczególnych czynności w przebiegu postępowania.

80 Por. co do nałożonego na lekarza obowiązku zgłoszenia (notyfikacji), o której mowa w art. 27 ustawy epidemiologicznej A. Augustynowicz, I. Wrześniewska-Wal, Ograniczenie autonomii pacjenta w diagnozowaniu i leczeniu gruźlicy, „Pneumologia i Alergologia Polska” 2013, nr 81, s. 131-132.

81 Por. H. Knysiak-Molczyk, (w:) T. Woś (red.), Postępowanie administracyjne, op. cit., s. 245.

82 Por. P. Dobosz, Procedury administracyjne, model sądownictwa administracyjnego a „prawo pomocy”, (w:) J. Stelmasiak, J. Niczyporuk, S. Fundowicz, Polski model sądownictwa administracyjnego, Lublin 2003, s. 125126; zob. co do prawa pomocy w postępowaniu związanym z przymusem psychiatrycznym M. Sychowicz, Postępowanie..., op. cit., s. 12.

83 A to ze względu na brak prawnych, jak również faktycznych możliwości wymuszenia zastosowania się do nakazu przez egzekutora administracyjnego; zob. T. Dukiet-Nagórska, Uwagi..., op. cit., s. 26; por. co do roli organów asystujących w stosowaniu przymusu bezpośredniego J. Radwanowicz, Przymus bezpośredni w egzekucji administracyjnej, (w:) J. Niczyporuk, S. Fundowicz, J. Radwanowicz, System egzekucji administracyjnej, Warszawa 2004, s. 492-493. Co do podziału obowiązków pomiędzy policję stosującą przymus bezpośredni a lekarza zob. rozważania M. Filara na gruncie dopuszczalności pobrania krwi, Prawne problemy pobrania krwi od osoby podejrzanej o popełnienie przestępstwa lub wykroczenia po użyciu alkoholu, „Prawo i Medycyna” 2003, nr 13, s. 52-53.

84 Zob. D.R. Kijowski, Austria, (w:) Z. Kmieciak (red.), Postępowanie administracyjne w Europie, Warszawa 2010, s. 70; A. Krawczyk, Merytoryczne orzekanie przez sądy administracyjne w Austrii w świetle założeń reformy sądownictwa administracyjnego (Verwaltungsgerichtsbarkeits-Novelle 2012, (w:) I. Lipowicz, Z. Kmieciak (współred.), Przyszłość sądownictwa administracyjnego w Polsce z uwzględnieniem tendencji europejskich, Warszawa 2012, s. 265; Z. Kmieciak, P. Florjanowicz-Błachut, Austria - reforma sądownictwa administracyjnego. Wybór 
środków władczych (verwaltungsbehördlicher Befehls). Ponadto ustawodawca powinien - mając na względzie kontrowersje związane ze stosowaniem administracyjnoprawnego przymusu bezpośredniego - przesądzić dopuszczalność doprowadzenia zobowiązanego na miejsce wykonania obowiązku jako następstwo braku posłuchu dla wydanej uprzednio decyzji administracyjnej.

Nieskrywane zamierzenie autorów stanowiła próba przedstawienia propozycji umożliwiającej optymalizację modelu postępowania przed organami policji sanitarnej z uwzględnieniem doświadczeń związanych z przymusowym leczeniem psychiatrycznym. Judycializacja postępowania ${ }^{85}$ oraz zapewnienie w większym stopniu ochrony praw jednostki wpływa również na zakres realizacji prawa do sądu ${ }^{86} \mathrm{w}$ sprawach dotyczących administracyjnoprawnego przymusu leczenia. Odstąpienie przez ustawodawcę od realizacji sądowej metody nakładania na jednostkę obowiązków ingerujących w autonomię pacjenta wymaga skorelowania obu postępowań, tj. postępowania administracyjnego (względnie egzekucyjnego) oraz sądowego postępowania kontrolnego ${ }^{87}$. De lega lata przy uwzględnieniu niedostatków postępowania przed organami policji sanitarnej, prawo do sądu, w omawianych przypadkach, nie jest w dostatecznym stopniu realizowane. Ze względu na ograniczone ramy niniejszego opracowania można wskazać jedynie sygnalnie na wybrane aspekty przedmiotowego zagadnienia. Po pierwsze, sądowa kontrola administracji publicznej ma charakter weryfikacyjny, a możliwości orzecznicze sądu są ograniczone do dopuszczalności wyeliminowania z obrotu prawnego zaskarżonego aktu lub czynności z zakresu administracji publicznej ${ }^{88}$. Po drugie, polski model sądownictwa administracyjnego cechuje normatywnie wpisana przewlekłość, która jest powodowana m.in. nadużywaniem przez skarżących swoich uprawnień procesowych ${ }^{89}$. W sposób szczególny daje się dostrzec rzeczoną tendencję w przypadku możliwości nieograniczonego kwestionowania czynności podejmowanych w administracyjnym po-

przepisów znowelizowanych 51. Ustawą federalną, Verwaltungsgerichtsbarkeits-Novelle 2012, „Zeszyty Naukowe Sądownictwa Administracyjnego" 2013, nr 4, s. 191.

85 Por. Z. Kmieciak, Zarys teorii..., op. cit., s. 101 i n.

86 Nie budzi wątpliwości kwestia doniosłości sądowej kontroli - co najmniej legalności - stosowania administracyjnoprawnego przymusu leczenia; zob. T. Dukiet-Nagórska, Uwagi..., op. cit., s. 28-29; M. Świderska, Zgoda pacjenta..., op. cit. s. 279 , która warunkuje stosowanie przymusu od sądowej kontroli.

87 Nie budzi zasadniczych wątpliwości okoliczność, że oba tryby ochrony prawnej pozostają w ścisłej korelacji. Tym samym za uprawnione wydaje się być ustalenie zależności stosownie do której im większy zakres gwarancji w postępowaniu administracyjnym, tym mniejsza możliwość ingerencji sądu w sferę działań administracji publicznej; zob. M. Bernatt, Konstytucyjne aspekty sądowej kontroli działalności administracji (między efektywnością a powściągliwością), „Państwo i Prawo” 2017, z. 1, s. 34. Modyfikując nieco na potrzeby niniejszego artykułu zarysowaną w piśmiennictwie proporcję można przyjąć, iż stopień realizacji uprawnień gwarantujących ochronę praw jednostki w postępowaniu administracyjnym warunkuje tryb postępowania sądu oraz sposób orzekania przezeń (np. kontrola de novo warunkowana minimalnym standardem ochrony praw jednostki w postępowaniu przed organem administracji publicznej).

88 Por. m.in. T. Woś, Komentarz do art. 1 ustawy - Prawo o postępowaniu przed sądami administracyjnymi, (w:) T. Woś (red.), H. Knysiak-Sudyka, M. Romańska, Prawo o postępowaniu przed sądami administracyjnymi, Komentarz, Teza 6-8, Lex Omega.

89 Por. analizę przyczyn przewlekłości postępowania sądowo-administracyjnego postanowienie NSA z 16 października 2015 r., I OSK 1992/14, Lex nr 1975884; H. Knysiak-Molczyk, Czy sądy administracyjne realizują prawo do sądu w aspekcie rozpatrzenia i rozstrzygnięcia sprawy w rozsądnym terminie?, op. cit., Warszawa 2012. 
stępowaniu egzekucyjnym, co prowadzi do globalnej przewlekłości postępowania, a w rezultacie niejednokrotnie czyni niemożliwym wyegzekwowanie obowiązku ${ }^{90}$.

W świetle poczynionych dotychczas uwag warto wskazać, że funkcjonujący de lege lata model stosowania administracyjnego przymusu leczenia nie może się ostać. Ograniczenie realizacji prawa do sądu poprzez wyłączenie możliwości przeprowadzania kontroli de novo jest uzasadnione wtedy i tylko wtedy, gdy w postępowaniu administracyjnym znajduje w pełni zastosowanie standard due process. Wówczas zgodnie z charakterem działalności kontrolnej, rola sądownictwa administracyjnego może być ograniczona li tylko do ochrony obiektywnego porządku prawnego. Racjonalizacja tego podejścia opiera się na założeniu, że ustawodawca uwzględnia systemowe następstwa wyboru drogi ochrony prawnej w danej kategorii spraw. Rezygnacja $\mathrm{z}$ formuły sądowego stosowania (zatwierdzania) przymusu leczenia winna uwzględniać potrzebę zmiany sposobu procedowania w sprawie przed organami administracji publicznej.

\section{BIBLIOGRAFIA}

Augustynowicz A., Czerw A., Stosowanie środków przymusu bezpośredniego przez personel medyczny $\mathrm{w}$ procesie diagnostyczno-terapeutycznym $\mathrm{w}$ podmiotach leczniczych innych niż szpitale psychiatryczne - zagadnienia wybrane, „Prawo i Medycyna” 2013, nr 1-2.

Augustynowicz A., Wrześniewska-Wal I., Aspekty prawne obowiązkowych szczepień ochronnych u dzieci, „Pediatria Polska” 2013, nr 88.

Augustynowicz A., Wrześniewska-Wal I., Ograniczenie autonomii pacjenta w diagnozowaniu i leczeniu gruźlicy, „Pneumologia i Alergologia Polska” 2013, nr 81.

Balicki M., Przymus w psychiatrii - regulacje i praktyka, „Prawo i Medycyna” 1999, nr 1.

Bernatt M., Konstytucyjne aspekty sądowej kontroli działalności administracji (między efektywnością a powściągliwością), „Państwo i Prawo” 2017, z. 1.

Boć J., Obywatel wobec ingerencji współczesnej administracji, Wrocław 1985.

Boratyńska M., Szczepienia ochronne małoletnich a wykonywanie władzy rodzicielskiej. Uwagi na tle wyroku NSA, „Prawo i Medycyna” 2013, nr 3-4.

Ciechorski J., Glosa do wyroku Sądu Apelacyjnego w Katowicach z dnia 15 stycznia 2014 r., I ACa 922/13, „Orzecznictwo Sądów Polskich” 2016, nr 6.

Daniel P., Egzekucja obowiązku poddania małoletniego dziecka szczepieniu ochronnemu w orzecznictwie sądów administracyjnych, „Przegląd Prawa Publicznego” 2014, nr 4.

Dąbrowski K. (red.), Zdrowie psychiczne, Warszawa 1985.

90 Por. T. Woś, Komentarz do art. 3 ustawy - Prawo o postępowaniu przed sądami administracyjnymi, (w:) T. Woś (red.), H. Knysiak-Sudyka, M. Romańska, Prawo o postępowaniu..., op. cit., Teza 41. Por. również krytykę efektywności przymusowego postępowania administracyjnego w kontekście prawa do sądu: wyrok ETPCz z dnia 3 maja 2011 r. w sprawie Apanasewicz przeciwko Polsce (skarga nr 35630/02). 
Dobkowski J., Policja administracyjna. Zagadnienia doktrynalno-instytucjonalne, „Samorząd Terytorialny" 2004, $\mathrm{nr}$ 7-8.

Dobosz P., Procedury administracyjne, model sądownictwa administracyjnego a "prawo pomocy”, (w:) Stelmasiak J., Niczyporuk J., Fundowicz S., Polski model sądownictwa administracyjnego, Lublin 2003.

Dukiet-Nagórska T., Uwagi na temat Ustawy z dnia 6 września 2001 r. o chorobach zakaźnych i zakażeniach, „Prawo i Medycyna” 2002, nr 11.

Filar M., Postępowanie lecznicze (świadczenie zdrowotne) w stosunku do pacjenta niezdolnego do zgody, „Prawo i Medycyna” 2003, nr 5.

Filar M., Prawne problemy pobrania krwi od osoby podejrzanej o popełnienie przestępstwa lub wykroczenia po użyciu alkoholu, „Prawo i Medycyna” 2003, nr 13.

Gert B., Culver C.M., Clouser K.D., Paternalism and Its Justification, (w:) Bioethics: A systematic approach, Oxford 2006.

Górski A., Leczyć czy nie leczyć? Dylematy podejmowania leczenia z punktu widzenia konfliktu dóbr, „Czasopismo Prawa Karnego i Nauk Penalnych” 2011, wydanie specjalne.

Górski A., Lekarz w procesie karnym (wybrane zagadnienia), (w:) Kardas P., Sroka T., Wróbel W. (współred.), Państwo prawa i prawo karne. Księga jubileuszowa Profesora Andrzeja Zolla, t. 2, Warszawa 2012.

Górski A., O obowiązku lekarza poinformowania pacjenta o zgodzie pacjenta na zabieg, „Studia Iuridica" 2001, t. XXXIX.

Gromek K., Ustawa o ochronie zdrowia psychicznego. Komentarz, Warszawa 2004.

Jadny-Jendrośka K., Jendrośka J., System jurysdykcyjnego postępowania administracyjnego, (w:) System prawa administracyjnego, t. 3, Wrocław - Warszawa - Kraków - Gdańsk 1978.

Janik M., Policja sanitarna, Warszawa 2012.

Jaworska I., Odmowa zaszczepienia dziecka i jej konsekwencje prawne, „Przegląd Prawa Publicznego” 2017, nr 3.

Jendrośka J., Potrzeba nowego modelu procedury prawnej w administracji, „Państwo i Prawo” 2003, z. 3.

Joerden J.C., Medizinstrafrecht - Einführung, (w:) J.C. Joerden, A.J. Szwarc, A.J. Yamanaka A.J. (red.), Das vierte deutsch - japanisch - polnische Strafrechtskolloqium der Alexander von Humboldt - Stiftung, Poznań 2011.

Karkowska D., Prawa pacjenta, Warszawa 2009.

Kędziora R., Kodeks postępowania administracyjnego. Komentarz, Warszawa 2014.

Kędziora R., Problematyka zgody pacjenta w świetle polskiego ustawodawstwa medycznego, „Prokuratura i Prawo" 2003.

Kijowski D.R., Austria, (w:) Kmieciak Z. (red.), Postępowanie administracyjne w Europie, Warszawa 2010.

Kijowski D.R. (red.), Ustawa o postępowaniu egzekucyjnym w administracji, Warszawa 2015.

Kisielewicz A., Akty i czynności, o których mowa w art. $3 \$ 2$ pkt 4 ustawy z 30 sierpnia 2002 r. Prawo o postępowaniu przed sądami administracyjnymi, (w:) Posłuszny J., Czarnik Z., Sawuła 
R. (współred.), Instytucje procesu administracyjnego i sądowoadministracyjnego, Przemyśl Rzeszów 2009.

Kmieciak Z., Florjanowicz-Błachut P., Austria - reforma sądownictwa administracyjnego. Wybór przepisów znowelizowanych 51. Ustawą federalną, Verwaltungsgerichtsbarkeits-Novelle 2012, „Zeszyty Naukowe Sądownictwa Administracyjnego" 2013, nr 4.

Kmieciak Z., Mediacja i koncyliacja w prawie administracyjnym, Kraków 2004.

Kmieciak Z., Zarys teorii postępowania administracyjnego, Warszawa 2014.

Knysiak-Molczyk (red.), Kodeks postępowania administracyjnego. Komentarz, Warszawa 2015.

Knysiak-Molczyk H., Czy sądy administracyjne realizują prawo do sądu w aspekcie rozpatrzenia i rozstrzygnięcia sprawy w rozsądnym terminie?, (w:) Lipowicz I., Kmieciak Z. (współred.), Przyszłość sądownictwa administracyjnego w Polsce z uwzględnieniem tendencji europejskich, Warszawa 2012.

Knysiak-Sudyka H., Klat-Wertelecka L., Model administracyjnego postępowania uproszczonego, „Państwo i Prawo" 2016, z. 7.

Korzan K., Postępowanie w sprawach ochrony zdrowia psychicznego, „Rejent” 1996, nr 6.

Krawczyk A., Merytoryczne orzekanie przez sądy administracyjne w Austrii w świetle założeń reformy sądownictwa administracyjnego (Verwaltungsgerichtsbarkeits-Novelle 2012, (w:) Lipowicz I., Kmieciak Z. (współred.), Przyszłość sądownictwa administracyjnego w Polsce z uwzględnieniem tendencji europejskich, Warszawa 2012.

Król M., Szukanie złotego środka - o zasadzie stosowania egzekucji najmniej uciążliwej dla zobowiązanego, „Przegląd Podatkowy” 2015, nr 8.

Kubiak R., Szczepienie dziecka bez obecności rodziców, „Medycyna Praktyczna”.

Lewandowski T., Glosa do wyroku NSA z dnia 8 lipca 2009 r., II FSK 618/08, Teza nr 3, Lex/el 2011.

Michalak K., Firlus J.G., Wybrane aspekty sądowej kontroli stosowania przymusu leczenia - przegląd zagadnień ze szczególnym uwzględnieniem szybkości postępowania, „Jurysta” 2016, nr 9.

Mikosz M., Konstrukcja i rozpoznawanie środków zaskarżenia bezczynności w ustawie o postępowaniu egzekucyjnym w administracji, „Samorząd Terytorialny” 2007, nr 7-8.

Moore C.H., Mediacje. Praktyczne strategie rozwiązywania konfliktów, Warszawa 2012.

Nelken J., O konieczności kontroli sądowej nad przymusowym umieszczeniem w szpitalu psychiatrycznym, „Nowe Prawo” 1983, nr 3.

Paprzycki L.K., Ochrona praw człowieka w świetle projektu ustawy o ochronie zdrowia psychicznego (część II), „Palestra” 1993, nr 11.

Paprzycki L.K., Stosowanie przymusu w postępowaniu psychiatrycznym (w świetle obowiązującego prawa oraz projektu ustawy o ochronie zdrowia psychicznego), „Postępy Psychiatrii i Neurologii" 1993, z. 2.

Radwanowicz J., Przymus bezpośredni w egzekucji administracyjnej, (w:) J. Niczyporuk, S. Fundowicz, J. Radwanowicz, System egzekucji administracyjnej, Warszawa 2004.

Rubin E., It's time to Make the Administrative Procedure Act Administrative, "Cornel Law Review” 2003, vol. 89 . 
Sawicki J., Przymus leczenia, eksperyment, udzielenie pomocy i przeszczep w świetle prawa, Warszawa 1966.

Sośniak M., Z problematyki zgody chorego na poddanie się zabiegowi leczniczemu, „Polski Tygodnik Lekarski” 1960, nr 46.

Starościak J., Prawne formy i metody działania administracji, (w:) System prawa administracyjnego, t. 3, Wrocław - Warszawa - Kraków - Gdańsk 1978.

Sychowicz M., Postępowanie sądowe w sprawach z ustawy o ochronie zdrowia psychicznego, „Przegląd Sądowy" 1995, nr 1.

Szpor A., Mediacja w prawie administracyjnym, (w:) Gmurzyńska E., Morek R. (współred.), Mediacje. Teoria i praktyka, Warszawa 2014.

Świderska M., Przymus leczenia i innych zabiegów medycznych, „Prawo i Medycyna” 2004, nr 3.

Świderska M., Zgoda pacjenta na zabieg medyczny, Toruń 2007.

Wegner-Kowalska J., Idea mediacji w postępowaniu administracyjnym, „Przegląd Prawa Publicznego” 2016, nr 10.

Woś T. (red.), H. Knysiak-Sudyka, M. Romańska, Prawo o postępowaniu przed sądami administracyjnymi. Komentarz, Warszawa 2016.

Woś T. (red.), Knysiak-Molczyk H., Krawiec A., Kamiński M., Kiełkowski T., Postępowanie administracyjne, Warszawa 2013.

Woś T., Postępowanie mediacyjne w ustawie - Prawo o postępowaniu przed sądami administracyjnymi, (w:) Podmioty administracji publicznej i prawne formy ich działania, Toruń 2005.

Wszołek P., Kryteria wyodrębniania prawa administracyjnego, Warszawa 2016.

Wulff H.R., Pedersen S.A., Rosenborg R. (przeł. Z. Szarawarski), Filozofia medycyny - wprowadzenie, Warszawa 1993.

Załuski W., Autonomia, (w:) Górski A. (red.), Leksykon prawa medycznego - 100 podstawowych pojęć, Warszawa 2012.

Zemke-Górecka A., Status prawny samodzielnego publicznego zakładu opieki zdrowotnej i jego prywatyzacja, Warszawa 2010.

Ziemski K.M., Ogólna charakterystyka działań (czynności) materialno-technicznych, (w:) R. Hauser, Z. Niewiadomski, A. Wróbel (współred.), System prawa administracyjnego, t. 5, Warszawa 2013.

Zimmermann J., Aksjomaty prawa administracyjnego, Warszawa 2013.

Zimmermann J., Polska jurysdykcja administracyjna, Warszawa 1996. 